\title{
Binational, Multidisciplinary and Evolutionary: Arctic's Tradition and the Future of the Arctic Institute
}

\author{
MICHAEL P. ROBINSON ${ }^{1}$
}

\begin{abstract}
In its 40 years of continuous quarterly publication, the journal Arctic has traced the intellectual history of Canadian and American northern science as driven by concerns for a variety for northern topics, including political systems, natural resources, military activities, cultural change, sovereignty assertion and natural science. Clearly, the future of northern scholarship deeply involves integrated polar information systems and some kind of centrally recognized polar institute entraining binationalism, a multidisciplinary approach and systematic circumpolar publication. Self-governing, self-reliant and land-owning tribal councils in Alaska, Yukon and the Northwest Territories will provide a further impetus to northern research beyond that already in place for 40 years, based largely upon renewable and non-renewable natural resources. The founding principles of the Institute will serve it well in the context of northern scholarship in the 1990s and 2000s, drawing support from recent Canadian and American evaluations of arctic science policy.
\end{abstract}

Key words: Arctic, Arctic Institute of North America, binationalism, multidisciplinary, northern science, northern scholarship

RÉSUMÉ. Durant ses 40 ans de publication trimestrielle ininterrompue, le journal Arctic a retracé l'évolution intellectuelle des études canadiennes et américaines sur le Nord. Ces études étaient motivées par des préoccupations qui se rattachaient à divers thèmes du Grand Nord comme le système politique, les ressources naturelles, l'activité militaire, le changement culturel, la question de la souveraineté et les sciences naturelles. Il est clair que l'avenir de la science du Grand Nord repose en très grande partie sur des systèmes d'information polaire intégrés et sur une sorte d'institut polaire centralement reconnu qui favoriserait un bi-nationalisme, une approche multidisciplinaire et des publications recouvrant toute la zone circumpolaire. Les conseils des tribus auto-gouvernées, auto-suffisantes et propriétaires des terres en Alaska, au Yukon et dans les Territoires du Nord-Ouest donneront un nouvel élan à la recherche dans le Grand Nord en plus de celle qui existe depuis 40 ans, à partir surtout des ressources renouvelables et non renouvelables. Les fondements de l'Institut continueront d'être valables dans le contexte des études nordiques durant les années 90 et au-delà, vu qu'ils ont été confirmés par de récentes évaluations faites par le Canada et les États-Unis sur les politiques de l'étude de l'Arctique.

Mots clés: Arctique, Institut Arctique de l'Amérique du Nord, bi-nationalisme, multidisciplinaire, science du Grand Nord, études nordiques

Traduit pour le journal par Nésida Loyer.

\section{INTRODUCTION}

Forty-two years of development of one legislative mandate with program refinements, changes, dead-ends, new opportunities and potential; 40 years of publication of Arctic with evolving design and format but one central purpose - the history of the Arctic Institute is inextricably bound up with its flagship publication, Arctic. The journal's development has created a continuous intellectual thread in the physical, biophysical, social and technical development of the North. Over 40 years a series of dedicated editors has nurtured in a very human way the maturing of an important scholarly journal. In its pages we find tangible proof of the evolving variety of circumpolar scholarship variety in disciplines, methodologies, sources of research funding, combinations of authors, locales and topics of study.

Given the relative and supposed lack of ideological restraints upon the development of science, it is extremely interesting to trace the birth and development of scientific ideas and their expression in the North. In the pages of Arctic we can follow the northern development of engineering and physics, environmental impact studies, cultural and wildlife resource management, native land claims and sustainable economic development. Reading between the lines, we arguably can see the pervasive ideologies of the times exercising their influence on the budgets and minds of scientists and in turn eventually appearing in the pages of Arctic. As a barometer of the trends in northern scientific publication, Arctic provides us with an intellectual history of northern scholarship.

In this special fortieth anniversary edition of Arctic you will read of the evolution of several northern topic areas: political systems, natural resources, military activities, cultural change, sovereignty assertion and natural science. The current editor of Arctic has chosen these general topics to give guest authors a rare opportunity - the chance to reflect in broad terms upon the evolution of their specialty. Briefly absent from this edition of
Arctic is the concern for the particular, the narrowly constrained, the controlled experiment. Here we find free rein for the expert to view and describe the big picture.

A very special contribution to this fortieth anniversary issue is the paper by summer student Roman Harrison and editor Gordon Hodgson. This content analysis of Arctic brings computeraided coherence to anecdotal speculation about the journal's contents. For the first time we learn about the nationality of authors, the frequency of national contributions and trends in the number of pages and authors per article. Given that this analysis is a comprehensive review of Arctic's contents, it may also be viewed as a content analysis of North American (and to some extent circumpolar) northern scholarship. The trends that emerge may seem obvious in retrospect and tend to confirm anecdotal supposition, but they now give us an authoritative, factual base upon which to forecast future trends.

\section{THE FUTURE OF NORTHERN SCHOLARSHIP}

If past performance, indicated by Harrison and Hodgson (1987), and a good deal of conventional wisdom are truly the best available criteria upon which to base projections of future performance, we now have a more coherent view of our northern scientific and scholarly future. At the most general level we can agree that:

- northern research is expensive and its conduct varies with national levels of affluence;

- given the above, national expenditure trends in the fields of northern defence, frontier exploration and government services tend to proportionally increase or decrease monies available for northern research; and

- as northern political autonomy increases, so does northern input increase to the setting of national northern research agendas.

\footnotetext{
'The Arctic Institute of North America, The University of Calgary, 2500 University Drive N.W., Calgary, Alberta, Canada T2N 1N4 (QT) Arctic Institute of North America
} 
Since the publication of National Needs and Arctic Research: A Framework for Action (May 1986) and Canada and Polar Science (March 1987), a much better informed debate on northern science priorities for the $1990 \mathrm{~s}$ and $2000 \mathrm{~s}$ has begun. In both the U.S. and Canada we have seen the call for greater public awareness of our scientific roles as arctic nations and for increased circumpolar cooperation in arctic research. The increased concern for arctic sovereignty in both nations belies a greater issue: the Arctic has become one of the world's most strategic areas.

The U.S. Arctic is one of the richest commercial fisheries in the world and is potentially the base of several new billiondollar industries. The Alaskan northern slope and the Canadian Beaufort contain immensely important strategic reserves of oil and gas. Lancaster Sound is an acknowledged point of entry for Soviet submarines into the North Atlantic and a similar channel of entry for U.S. submarines to gain access to Soviet fleet activities in the Barents Sea. All of the above examples contribute to the emerging profile of northern scholarship in the next two decades. In concrete terms it augurs for applied, problemoriented research supplemented with related basic research.

The U.S. Arctic Research Commission in its 1986 annual report (1987:10-12) stresses the future need for a multidisciplinary approach, including both long- and short-term studies. It is interesting to note how its multidisciplinary nature, the thematic core of Arctic, continues to thrive in this reading of the future of northern research. From a disciplinary standpoint the Arctic Research Commission heard briefs in 1986 calling for greater research effort to be addressed to ice dynamics, weather forecasting, atmospheric effects on communications and defense systems, health, fisheries and geopolitical and jurisdictional problems. The importance of international cooperation in this research was also a common theme, with much advice rendered on the "hows" of improved communication.

Both the U.S. Arctic Research Commission and the authors of Canada and Polar Science have given careful thought to the development of improved data systems and networks to communicate scientific findings. Establishment of an arctic (or "polar" in the Canadian usage [Adams et al., 1987:114-115]) information system is both a goal and objective of the U.S. Arctic Research Policy and recommendation number 3 of the authors of Canada and Polar Science. Clearly the creation of such a system is an idea whose time has come and come again. It is also continually expressed in a binational context. Acting on this perceived need, the Institute's Canadian corporation has recently begun negotiations with the Boreal Institute for Northern Studies to combine both institutes' online databases into one national system of excellence. Realizing that the costs of maintaining such a system are persistent and higher than the present database budget allocations of both institutes, a proposal for federal support has been sent to the Minister of Indian Affairs and Northern Development. Ideally the Arctic Science and Technology Information System (ASTIS), developed over the past decade by the Canadian corporation, will become the foundation of the national polar information system envisaged by the authors of Canada and Polar Science.

From our perspective, the contemporary demand for circumpolar information systems with a multidisciplinary approach and an applied focus is a continuing indication of the fundamental wisdom of the fathers of the Arctic Institute of North America. In their endorsement and incorporation of binationalism, a multidisciplinary approach and systematic circumpolar publi- cation, they showed an uncanny vision of the future of northern scholarship. If the Arctic Institute did not exist in 1987, one would be tempted to create it.

\section{THE FUTURE OF THE ARCTIC INSTITUTE}

In meeting the challenges of the next 40 years, the Arctic Institute must continue to work to its strengths and develop new areas of allied expertise. In 1987 the strengths of the Institute are its continued binational identity, its growing public membership (over 2400 members and subscribing institutions at time of writing), its distinguished list of fellows and supportive life members, its diverse budget support from the public and private sectors, its two Canadian research stations, the Arctic Science and Technology Information System, the monthly newsletter Information North and the journal Arctic.

One also cannot help but notice the flexibility inherent in the institution. Rather than tie itself to one source of funding, the Institute has been fast on its feet, accommodating moves from McGill University to the University of Calgary and from Washington, D.C., to the University of Alaska, Fairbanks, without losing touch with the membership. While the academic and administrative venues have changed, Arctic remains the constant source of communication with a growing readership.

The Canadian corporation of the Institute has recently begun a new mission, the Northern Information Homecoming, based upon the perceived need in the Canadian North for critically analyzed state-of-the-art information in six defined areas: land use planning, building science, sustainable economic development, self-government development, science and technology and humanities curricula development. In each of the six areas outlined the Institute plans to hire a research associate with cutting-edge skills. The new research associates will prepare the state-of-the-art assessments with a view to their publication and widespread distribution in the North. It is anticipated that northern decision makers will benefit from both the critical assessment of the information and the secondment of the authors to work alongside local organizations in delivering development advice and assistance. The secondment of research associates will also give the Institute's work a human face in the North. Together the six new research associates will deliver the Research, Publication and Secondment (RPS) Program of the Northern Information Homecoming.

Once again relying on multiple sources of support, the Canadian corporation has begun a major fund-raising appeal to mobilize \$1.6 million in new funds to implement the RPS Program. To date two Alberta-based foundations have pledged support for this new venture, and the Institute is now actively seeking corporate sector support. By combining industry, government and charitable foundation funding with the demonstrated northern need for critically assessed information, the Canadian corporation of the Institute is moving into the next decade with goals clearly defined and a work plan in place.

The American corporation, headquartered since 1984 at the University of Alaska, Fairbanks, continues to struggle for secure sources of funding, but annually contributes significantly to the membership of the Institute and the publication of Arctic. On 13 May 1987 the executive director of the Canadian corporation and the chairman and executive secretary of the U.S. corporation addresssed a potluck dinner in Fairbanks for Institute members that was attended by over 70 people. From the 


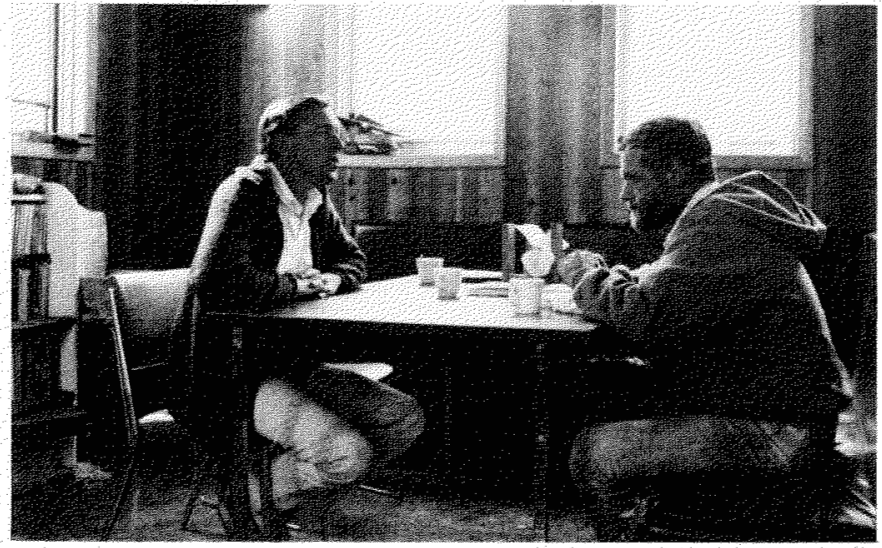

FIG. 1. Michael Robinson, executive director of the Arctic Institute of North America, Canadian Corporation, and David Norton, executive secretary of the Arctic Institute of North America, U.S. Corporation, in the Kluane Lake Research Station developing plans for the future of the Institute.

Institute's perspective it was clear that night that the spirit of binationalism is alive and well.

In 1986 BITNET electronic mail linkages were established between the two Institute head offices, and almost daily exchange of information ranging from scientific to administrative has begun. More recently BITNET communications links have also been established with the Scott Polar Research Institute in Cambridge, the Institute for Arctic and Alpine Research in Boulder, the Boreal Institute for Northern Studies in Edmonton and the University of Trondheim in Norway.

At present the U.S. corporation has a series of projects under way, including:

- the production of a Beaufort Sea Fisheries synthesis monograph; - the Pioneers of Transpolar Aviation Project, contemplating the eventual publication of a book;

- the collection of Bill Field's photographs of Alaska glaciers; - the acquisition of Roald Amundsen's magnetic data for the North American Arctic;

- a joint venture with the Rasmuson Library, University of Alaska, Fairbanks, and the Canadian corporation to place the Arctic Bibliography online (pending government funding approval);

- long-term environmental and cultural research opportunities in northwest Alaska (funded by the National Science Foundation through the Alaska Quaternary Center);

- a cooperative agreement with the North Slope Borough that will assist students and other young scholars with work of interest to both the Borough and the Institute; and

- promotion of publication of Blue Babe, a book on the excavation and investigation of the remains of a 36000 -year-old Pleistocene steppe bison from near Fairbanks.

The Canadian corporation also has several research projects under way, in the form of the ongoing work of current research associates. Unlike the planned Institute-sponsored research of the RPS Program, the following projects are funded through a variety of independent sources, including major foundation grants and the Social Sciences and Humanities Research Council: - Research associate Frances Abele is completing the final report of the Native Employment Training Study. This study reviewed and evaluated several northern training programs with a view to isolating factors that promote program success from both a community and an agency perspective.

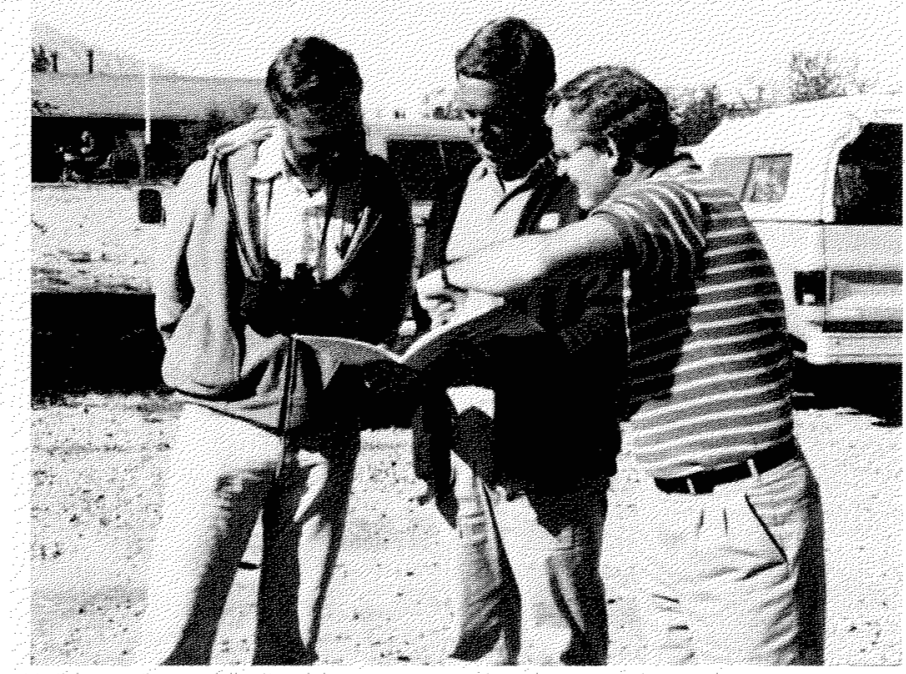

FIG. 2. David Norton, executive secretary of the Arctic Institute of North America, U.S. Corporation, Michael Robinson, executive director of the Arctic Institute of North America, Canadian Corporation, and Gerald Thompson, associate director of the Canadian Corporation, discussing the 1987 annual report of the Institute in front of the Kluane Lake Research Station in southwest Yukon, Canada.

- Research associate Michael Pretes, a doctoral student in Political Science at the University of Calgary, is working on a comparative study of the Alberta Heritage Savings Trust Fund and the Alaska Permanent Fund, both of which have attempted to utilize resource revenue to increase social benefits.

- Research associate Betty Harnum, a Master's candidate in linguistics at the University of Calgary, is studying the evolution of the Canadian Inuktitut language and the related Yupik and Inupiat. She is especially interested in language changes that have stemmed from the introduction of southern technology into Inuit society.

- Research associate Wanda Wuttunee, a graduate student in the Faculty of Management at the University of Calgary, is conducting an examination of the financial goals and policies of the 13 native regional corporations created by the Alaska Native Claims Settlement Act of 1971.

- Research associate Constance Martin is working with Chauncey Loomis, of Dartmouth College, New Hampshire, on a book that will focus on images of the Arctic as written, drawn or painted by early explorers and on their impact on society's vision of the polar regions.

- Research associate Leo Bushman is preparing a first exhibition of the collected paintings of Dewey Soper, an eastern High Arctic pioneer in natural history studies.

- Research associate Robert MacDonald is collecting northern history materials with a view to preparing an introductory text to northern studies.

- Research associate Gerald Holdsworth is continuing to utilize the Institute's Kluane Lake Research Station to pursue paleoclimatological analysis of a 103-metre ice core taken from Mount Logan in 1980.

- Research associates Karen McCullough and Peter Schledermann are continuing the work of the Ellesmere Island archaeologi- 
cal research project begun in 1977. This work focuses on regional culture history of the Thule culture continuum in the eastern Canadian High Arctic.

All of the above projects continue to support the Institute's tradition of a multidisciplinary approach and testify to the U.S. and Canadian corporations' continued intellectual vigour.

Together the two original corporations are well positioned to contribute to many aspects of arctic scholarship in the coming decades. The contributions to come will be less comprehensive than the role originally conceived for the Institute in 1945, but they will focus on historic strengths and demonstrated areas of competency. Gazing into an arctic crystal ball, we see the Institute operating the acknowledged circumpolar online information system in conjunction with the Boreal Institute for Northern Studies. We see Arctic firmly occupying the role of a multidisciplinary journal of excellence and enjoying a broader readership as the Institute's public membership greatly increases. The newsletter Information North will also flourish as the layman's Arctic, reaching an expanding public through newsstand sales. Binational conferences on northern topics of transboundary significance will be held at the Kluane Lake Research Station, and the published proceedings will significantly influence U.S.-Canadian arctic policy development. The U.S. corporation will join with the Canadian corporation in a successful fund-raising drive, which will result in the appointment of a wide range of Institute-sponsored research associates. Their collective multidisciplinary expertise will strengthen the Institute's non-governmental organization (NGO) status and provide the base for a range of applied and basic research.

Both the strategic importance of the Arctic and the emerging importance of self-governing, self-reliant and land-owning tribal councils in Alaska, the Yukon and the Northwest Territories will provide the impetus for a new northern research agenda. This will increasingly be dominated by northern resident scholars, working out of truly northern universities. Prime topics of future study will be political evolution, local sustainable economic development, cross-cultural education and the resolution of community-based health problems, such as fetal alcohol syndrome. While in many respects this vision of northern research is the polar opposite of that envisioned in 1945, the Institute will be an integral part of its evolution and a shared participant in its practice. Flexible, cooperative, binational, multidisciplinary, evolutionary and funded by a broad base of interests, the Arctic Institute of North America looks out on the future with sharply honed survival skills and a clear vision of its continuing mandate.

\section{REFERENCES}

ADAMS, W.P., BURNET, P.F., GORDON, M.R., and ROOTS, E.F. 1987. Canada and Polar Science. Ottawa: Circumpolar and Scientific Affairs Directorate, Department of Indian Affairs and Northern Development. 116 p.

HARRISON, R., and HODGSON, G. Forty Years of Arctic: The Journal of the Arctic Institute of North America. Arctic 40:321-345.

U.S. ARCTIC RESEARCH COMMISSION. 1986. National Needs and Arctic Research: A Framework for Action. Report of the U.S. Arctic Research Commission to the President and Congress of the United States of America. Los Angeles: U.S. Arctic Research Commission. 50 p.

1987. The United States: An Arctic Nation. Report of the U.S. Arctic Research Commission to the President and the Congress of the United States of America, for the Period 1 October 1985 - 30 September 1986. Los Angeles: U.S. Arctic Research Commission. 46 p. 